\title{
THE FACTORS INFLUENCING ATTITUDE OF “ESPORTS” PEOPLE IN BANGKOK, THAILAND
}

\author{
Pachoke Lert-Asavapatra
}

Suan Sunandha Rajabhat University, Bangkok, Thailand

Electronic Computer Sport is a video game competition, characterized by using virtual space competitive features, which are generated by computer programs. The development of esports, on the one hand, implies the emergence of new industries, forms of commercial activity with a high investment attractiveness. On the other hand, critics of the e-sports concept in Thailand are increasingly claiming the negative consequences of its development, such as an increase in the young people dependence on gadgets, a change in their consciousness and attitude, an increase of young people unreadiness to live in the real world. The article presents results of study of Bangkok residents and their relationship to the problem of electronic sports, outlined the prospects for its legalization and growth of attractiveness for Thai business.

Keywords: information technology, eSport, ICT, Bangkok

\section{Introduction}

eSports or Electronic Computer Sport is a video game competition, characterized by using virtual space competitive features, which are generated by computer programs. It is also a term used to define the meaning of video games competition, which refers to the genre, the variety form of the game, including the perspective from first players or first shooters, sport games simulation, speed racing game, action games, and real time virtual gaming.

In various game competitions, there are both single competition characteristics and the team competition characteristic, and also the form of competition between professional players is available as other general sports or traditional sports.

eSports is the competition that requires skill, ability, strategy, tactics in planning, concentration, communication among the players, the unity of the team members as well as the tough training same as other sports (Lu, 2017). However, in order to be listed in the Electronic Sport game or eSports, it must be officially recognized and considered by the international eSport competition.

Although there are opposition from many studies, from various articles, and various academic reports or research in the manner that "Should eSport be considered as a sport?".

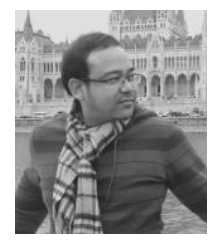

Pachoke Lert-Asavapatra

works in College of Innovation and management, Suan Sunandha Rajabhat University,

Bangkok, Thailand, member of evaluation team

Research interests : eSport, digitalization, innovative economy

E-mail: pachoke le@ssru.ac.th 
As in Jim Parry's (2018) research, which commented that the computer game is not in the scope of what can be considered a "Sport". Same as in Thailand, where the movement of various government agencies remains a controversial issue on the definition of the word "Sport", that it must be something that results in health effects or the formation of the physical skills (Physical skills). Nevertheless, if the definition would be defined as the reason mentioned above, then in the case of some recognized sports that have already been accepted in the Olympic Games such as chess, bridge cards should not be defined as sports as well.

However, from the paper of Mariona Rosell Llorens (2017), she has studied the definition of the word "sport" in the context of eSports and also explained that, it could be a lot of possibility to accept that eSport is a sport as the video game competition consists of various circumstances that can be defined and considered in the context of "sport" section. For example, the video game competition must be done with the aim of overcoming competitors and any action must be preceded under the rules set. Moreover, must have an interaction among all competitors. Where of, any actions in such a competition requires a concentration, specific ability, precision, body control, knowledge of how to use the strategy in the game, all these concepts are closed to the definition of the word "sport" significantly.

The research of Juho Hamari \& Max Sioblom (2016) has also defined that eSports is one type of a sport with activities that are directed through electronic system only. Where of any actions or activities either in the form of a single player (Player) or in the form of a team player will be processed through the operating system and display through the screen.

Although there is still ambiguity in defining eSports as "Sports" as well as other general sports, as mentioned above but it is undeniable that the current competition in eSports is widely popular. This is reflected by plenty number of viewers and fans of eSports, Including the high-value of revenues generation that are likely to grow more continuously in the future. (BBC, 2017). The revenue, estimates and trends of growth are shown in Fig.1.

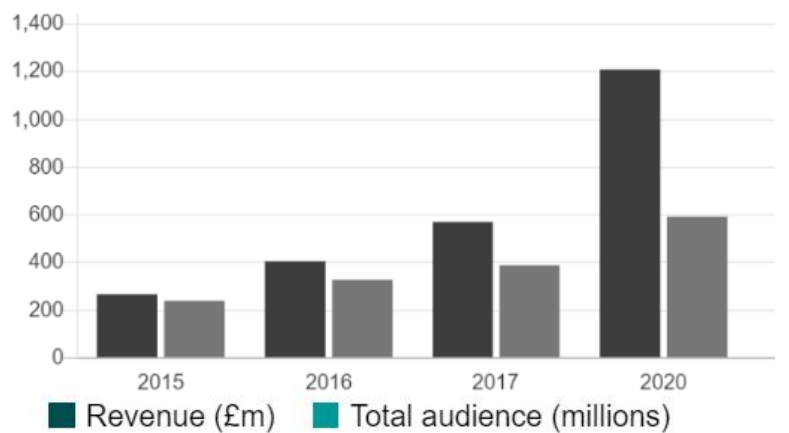

Figure 1 - Trend of revenue and the number of eSport viewers (Source: BBC, 2017.)

Michael Borowy (2013) studied eSports capabilities to generate economic value and to be used as a marketing. Since 1980 eSports has been used in promotion, connection of brands and products with the eSport competition. In 2017 it was revealed that eSports is a business that contributes to the global economy about $\$ 465$ million.

In Thailand, Thai eSports Association has been established and registered by the Bangkok Registrar Association on 6th June, 2013with the purposes to develop relevant 


\section{THE FACTORS INFLUENCING ATTITUDE OF “ESPORTS”}

personnel, eSports athletes, set the rules both domestic and international to let the Thai eSports-man to have the rights as representatives to participate in every competition organized by the International Electronic Sports Federation (International eSport Federation).

Even Department of Children and Youth of Thailand initiated a big discussion on eSports demand in society, on $27^{\text {th }}$ July 2017, the Ministry of Tourism and Sports of Thailand passed a resolution to approve eSports as a type of ones can be registered and established as a sports association.

Undoubted it creates many business opportunities but at the same time Thai society received a lot of negative information about games (for example, children addiction on electronic games)

Therefore, in order to achieve long-term sustainability and create confidence in any investment related to this type of business, we are interested to conduct the presented study.

\section{Hypotheses of the study:}

H1: Participation factors have a direct positive influence towards identification.

$\mathrm{H} 2$ : Participation factors have an indirect positive influence on the attitude towards eSports through identification factors.

H3: Participation factors have a direct positive influence on the attitude towards eSports.

\section{Research Methodology}

\section{The population}

The population used in the study, is the people who live in Bangkok metropolitan area both male and female who knows about eSport competitions, both from the media and from experiencing themselves. 385 samples were determined as the sample size in this study

\section{Research tools}

We used questionnaires as a tool for data collection. The questions in the questionnaire were a closed-ended question which divided into 2 parts:

Part 1 General information of respondents.

Part 2: The level of opinion about factors contributing to eSports.

Identification factors as an eSport viewers (Identification) and the level of opinions about the attitude towards eSports (Tab. 1).

\section{Tools, quality inspection}

The researcher has examined the accuracy of the content by sending the questionnaires to eSports professionals (eSport club operators, various experts of the eSport, academic experts) for validation of the content coverage, including language used.

Next, the researcher examined the questionnaire reliability by conducting a reliability testing. 
Table 1 -The source and questionnaire attribution (made by the author)

\begin{tabular}{|c|c|}
\hline Question & Reference \\
\hline $\begin{array}{l}\text { I am delighted if the eSports will be accepted and } \\
\text { broadly recognized }^{1}\end{array}$ & $\begin{array}{l}\text { (Gwinner, 2003) } \\
\text { (Kim, 2014) }\end{array}$ \\
\hline $\begin{array}{l}\text { When the media presents a bad story about the } \\
\text { eSport competition, I feel ashamed }{ }^{1}\end{array}$ & $\begin{array}{l}\text { (Gwinner, 2003) } \\
\text { (Kim, 2014) }\end{array}$ \\
\hline $\begin{array}{l}\text { I feel happy to be able to participate in the eSports } \\
\text { competition }\end{array}$ & (Kim, 2014) \\
\hline I oftenlythink of the e-sport competition ${ }^{2}$ & (Kim, 2014), (Gwinner, 2003) \\
\hline $\begin{array}{l}\text { I will watch the eSport competition every time } \\
\text { when there is a chance }\end{array}$ & (Kim, 2014), (Gwinner, 2003) \\
\hline I am a true eSports fan ${ }^{2}$ & (Kim, 2014), (Gwinner, 2003), \\
\hline Feel good with eSport(Bad-Good) & (Gwinner, 2003) \\
\hline Feel like with eSport(Unfavorable-Favorable) & (Gwinner, 2003) \\
\hline $\begin{array}{l}\text { Feeling satisfied with eSport (Unsatisfactory- } \\
\text { Satisfactory) }\end{array}$ & (Gwinner, 2003) \\
\hline
\end{tabular}

\section{Research Results}

\section{The demographic characteristics analysis results}

Data analysis on demographic characteristics, consists of information on gender, age, educational level, occupational status, average monthly income, which shown in Tab. 2

Table 2 - Analysis of respondents' demographic characteristics (made by the author)

\begin{tabular}{|l|c|c|}
\hline \multicolumn{1}{|c|}{ General information } & Number (person) & Percentage \\
\hline Gender & & \\
\hline Male & 258 & 67 \\
\hline Female & 127 & 33 \\
\hline Total & 385 & 100 \\
\hline Age & & \\
\hline Less than or equivalent to 20 years & 89 & 23.1 \\
\hline 21-25 year & 189 & 49.1 \\
\hline 26-30 year & 41 & 10.6 \\
\hline $31-35$ year & 18 & 4.7 \\
\hline $36-40$ year & 7 & 1.8 \\
\hline $41-45$ year & 6 & 1.6 \\
\hline $46-50$ year & 33 & 8.6 \\
\hline
\end{tabular}


THE FACTORS INFLUENCING ATTITUDE OF "ESPORTS"

\begin{tabular}{|l|c|c|}
\hline More than 50 years & 2 & 0.5 \\
\hline Total & 385 & 100 \\
\hline Educational Level & & \\
\hline Lower than high school & 8 & 2.1 \\
\hline High School / Vocational & 46 & 11.9 \\
\hline Diploma / Vocational & 269 & 3.9 \\
\hline Bachelor & 40 & 69.9 \\
\hline Master's degree & 7 & 10.4 \\
\hline Higher than the master's degree & 385 & 1.8 \\
\hline Total Independent & & 100 \\
\hline Occupation / Trading / & 23 & \\
\hline $\begin{array}{l}\text { Owner / } \\
\text { Occupation }\end{array}$ & 36 & 6 \\
\hline Bureaucrat & 233 & 9.4 \\
\hline $\begin{array}{l}\text { Students / College' Students/ University } \\
\text { Students }\end{array}$ & 5 & 60.5 \\
\hline State employees & 70 & 1.3 \\
\hline $\begin{array}{l}\text { Private company employees / general } \\
\text { contractors }\end{array}$ & 2 & 18.2 \\
\hline Housewife & 16 & 0.5 \\
\hline Others & 385 & 4.2 \\
\hline Total & & 100 \\
\hline Marital Status & 331 & \\
\hline Single / Separated & 54 & 86 \\
\hline Married / together & 385 & 14 \\
\hline Total & & 100 \\
\hline The average income per month & 176 & 45.7 \\
\hline Lower or equivalent to 10,000 Baht & 94 & 24.4 \\
\hline 10,001-20,000 & 45 & 11.7 \\
\hline 20,001-30,000 & 18 & 4.7 \\
\hline 30,001-40,000 & 14 & 3.6 \\
\hline 40,001-50,000 & 10 & 2.6 \\
\hline $50,001-60,000$ & 385 & 100 \\
\hline More than 60,000 Baht & & \\
\hline Total & & \\
\hline
\end{tabular}

\section{Factor analysis}

The factor analysis results, shown in Tab. 4 . 
Table 3 - The average level data and standard deviations of variables observed analysis results

((made by the author)

\begin{tabular}{|c|c|c|}
\hline General information & median & Standard deviation \\
\hline IDEN1 & 4.44 & 0.734 \\
\hline IDEN2 & 3.50 & 1.118 \\
\hline IDEN3 & 4.27 & 0.828 \\
\hline INVO1 & 3.49 & 1.008 \\
\hline INVO2 & 3.79 & 1.193 \\
\hline INVO3 & 3.81 & 1.332 \\
\hline ATTI1 & 3.91 & 0.942 \\
\hline ATTI2 & 3.75 & 0.929 \\
\hline ATTI3 & 3.81 & 0.930 \\
\hline
\end{tabular}

Table 4- The average and standard deviations of observed variables analysis results (made by the author)

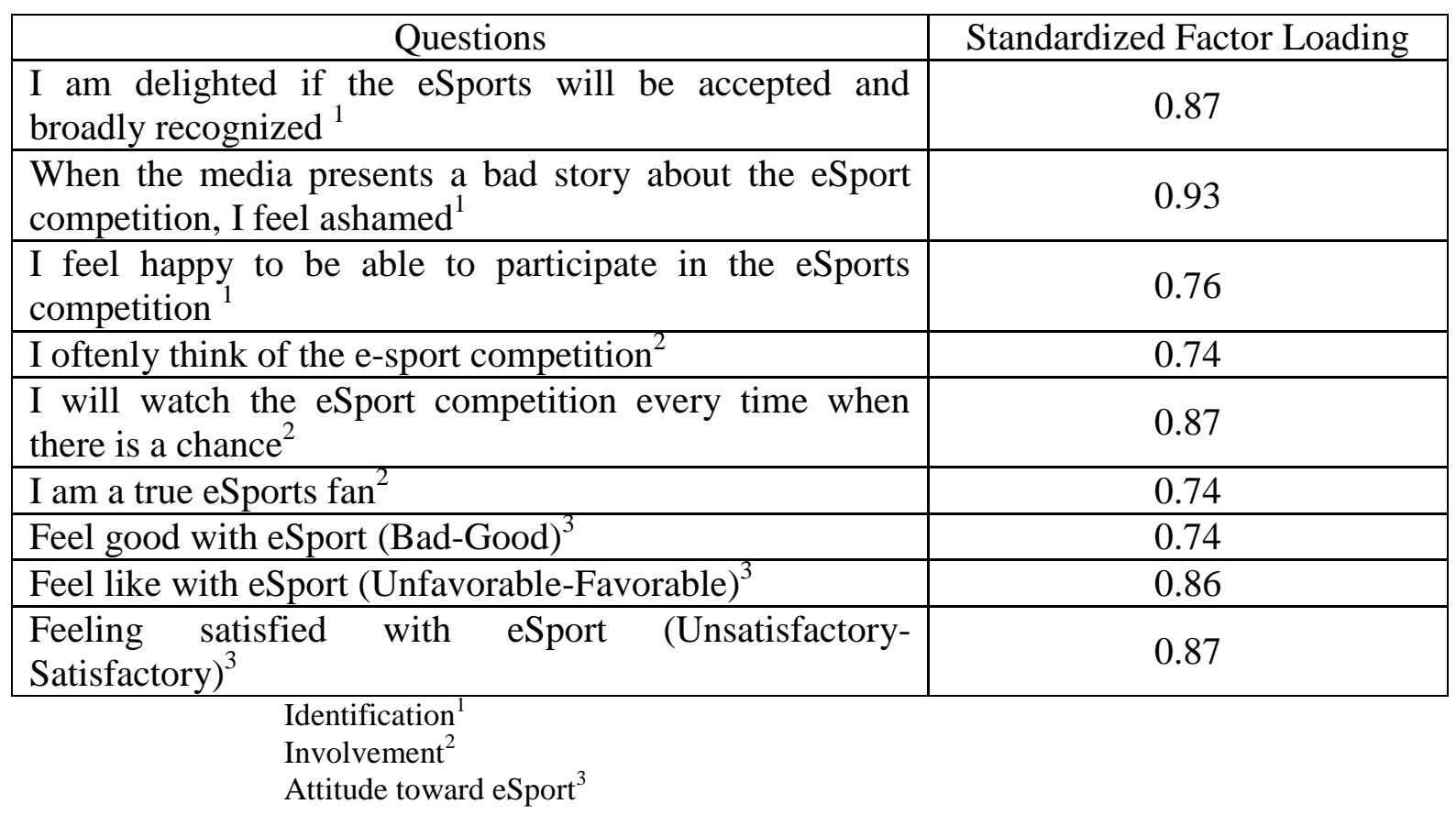

\section{The confirmatory factor analysis Results (Confirmatory Factor Analysis: CFA)}

The researchers conducted a confirmatory factor analysis of the structural equation model as shown in Fig. 3. The finding indicated that the models are in consistent with the empirical data in a very good criterion, with a CMIN / DF equals to 1.676, GFI equals to 0.977, NFI equals to 0.979 , RFI equals to 0.969 , IFI equals to 0.992 , TLI equals to 0.987 , CFI equals to 0.992 and RMSEA equals to 0.042. All statistics have passed the criteria for conformance with an empirical data, as shown in Tab. 5. 


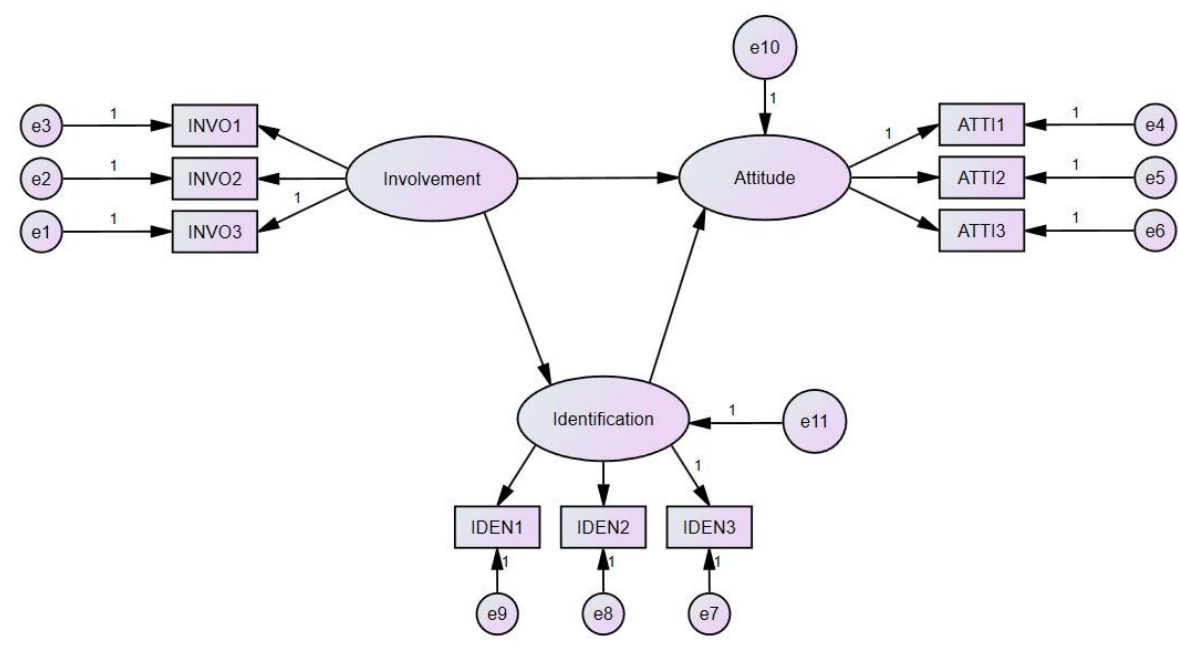

Figure 4 - The Structural equation model of factors influencing electronic sports attitudes of citizens in Bangkok

(authors model)

Table 5 - Confirmatory factor analysis results (made by the author)

\begin{tabular}{|l|c|c|}
\hline Fit Indices & Recommended Value & Results \\
\hline CMIN/DF & $<5$ Loo \& Thorpe (2000) & 1.676 \\
\hline Goodness of Fit Index (GFI) & $\geq 0.8$ Cheng, Shih-I (2011) & 0.977 \\
\hline Normalised Fit Index (NFI) & $\geq 0.9$ Bentler (1999) & 0.979 \\
\hline Relative Fit Index (RFI) & $\geq 0.9$ Bentler (1999) & 0.969 \\
\hline Incremental Fit Index (IFI) & $\geq 0.9$ Bentler (1999) & 0.992 \\
\hline Tucker Lewis Index (TLI) & $\geq 0.9$ Bentler (1999) & 0.987 \\
\hline Comparative Fit Index (CFI) & $\geq 0.9$ Bentler (1999) & 0.992 \\
\hline $\begin{array}{l}\text { Root mean square error of approximation } \\
\text { (RMSEA) }\end{array}$ & $<0.08$ Hair et al (1998) & 0.042 \\
\hline
\end{tabular}

The hypothesis according to Tab. 5, indicated that the hypothesis 1 was accepted at the statistical significance value level at 0.001 . The P-value is 0.000 and the weight factors equal to 0.432 .

The hypothesis 2 was accepted at the statistical significance value level at 0.001 . The P-value equal to 0.000 and the weight factor equals to 0.187 .

The hypothesis 3 was accepting at the statistical significance value level at 0.001 . The P-value is 0.000 and the weight factor equals to 0.355 , as shown in Tab. 6 
Table 6 - The hypothesis testing Results (obtained by the author)

\begin{tabular}{|l|l|l|l|}
\hline \multicolumn{1}{|c|}{ Hypothesis } & $\begin{array}{c}\text { Factor } \\
\text { loading }\end{array}$ & $\begin{array}{c}\text { P- } \\
\text { value }\end{array}$ & Result \\
\hline $\begin{array}{l}\mathrm{H}_{1} \text { Participation factors have a direct positive influence } \\
\text { towards identification. }\end{array}$ & 0.432 & 0.000 & Accepted \\
\hline $\begin{array}{l}\mathrm{H}_{2}: \text { Participation factors have an indirect positive influence } \\
\text { on the attitude towards eSports through identification factors }\end{array}$ & 0.187 & 0.000 & Accepted \\
\hline $\begin{array}{l}\mathrm{H}_{3}: \text { Participation factors have a direct positive influence on } \\
\text { the attitude towards eSports. }\end{array}$ & 0.355 & 0.000 & Accepted \\
\hline
\end{tabular}

Note $* * *$ means the significance level of $0.001, *$ means the significance level of 0.05

Table 7 - The influences analysis results (Path Analysis) (made by the author)

\begin{tabular}{|l|c|c|c|}
\hline \multicolumn{1}{|c|}{ Path Analysis } & $\begin{array}{c}\text { Direct } \\
\text { Effect }\end{array}$ & $\begin{array}{c}\text { Indirect } \\
\text { Effect }\end{array}$ & Total Effect \\
\hline Involvement $\rightarrow$ Identification & 0.432 & - & 0.432 \\
\hline Involvement $\rightarrow$ Attitude & 0.355 & 0.187 & 0.542 \\
\hline
\end{tabular}

From Tab. 7, showing the influences path analysis (Path Analysis), both direct effect (Direct Effect), indirect effect (Indirect Effect) and total effect (Total Effect). The researcher found that the involvement factors had a direct influence on Identification with the weight factors equal to 0.432 with statistical significance at 0.001 .

Involvement factors had a direct influence on attitude with the weight factors equal to 0.355 with statistical significanceat 0.001 and has an indirect influence on the attitude with a load factorsequal to 0.187 , with a significant level at 0.001 . Total influence among involvementfactors towards the attitude was at 0.542 .

\section{Suggestions}

\section{Theoretical suggestions}

This research provides an empirical data that factors influencing electronic sports attitudes of citizens in Bangkok, have a direct impact on the attitude of eSports. Therefore, an increasing level of participation and identification increase the positive attitude towards eSports as well. This will be resulted in an acceptance of the hypothesis which has been set. This research provides guidelines for the confirmatory factor analysis study of structural equations models of various factors which is reliable and confirms the validity of the questions.

\section{Suggestions for executives and entrepreneurs}

Entrepreneurs who want to invest in any trading business that offering their production in the form of products or services related to competition activities of eSports in Bangkok, should increase the level of involvement with eSports for local citizen. Executives or entrepreneurs may use various methods of strategy such as organizing activities to encourage 


\section{THE FACTORS INFLUENCING ATTITUDE OF “ESPORTS”}

consumers to experience the activity by watching eSport competitions regularly and creating additional values for these consumers through various media and mass communication organizations.

\section{Reference:}

BBC (2017). Esports: International Olympic Committee considering esports for future Games. Available. : http://www.bbc.com/sport/olympics/41790148.

Borowy, M. \& Jin, D. (2013). Pioneering E-sport: The Experience Economy and the Marketing of Early 1980s Arcade Gaming Contests. International Journal of Communication. 7(13): 22542274.

Gwinner, K. (2003). A model of Fan Identification: Antecedents and Sponsorship Outcomes. Journal of Service Marketing. 17(3): 275-294.

Hamari, J. \& Sjoblom, M. (2016). What is eSports and why do people watch it? Internet Research. 27(2).211-232.

Kim, Y., Lee, H., Magnusen, M., \& Kim, M. (2015). Factors Influencing Sponsorship Effectiveness: A Meta-Analytic Review and Research Synthesis. Journal of Sport Management. 15.

Lu, Z. (2017). From E-Heroin to E-Sports: The Development of Competitive Gaming in China. The International Journal of the History of Sport. 33(18): 2186-2205.

\section{References:}

Chunkingtong, K. (2006). Factors Affecting Doing Research of University Teacher at Songkhla Province. Research report. Hat Yai University

Chunphom, K. et al. (2007). Study Research Management System Development Pproject, Walailuck University. Thailand Research Fund (TRF). Available at: from http://digi.library.tu.ac.th/thesis/jc/1519/09CHAPTER_2.pdf

Kompol, S. (2010). System and supporting mechanism for permanent teachers to do the research for development teaching in Rumbhai Barni Rajabhat University in 2010. Rumbhai Barni Rajabhat University.

Piboolchol, C. et al. (2005). Study the research creation status and academic performance of teachers in faculty of human: factor to contribute, obstacle and development guidelines. Journal of Humanities. 27: 68-78.

Prayrupitak, S. et al. (2007). Strength development guideline in research management system of Payap University. Document Management and document storage. Available at: www.tatc.ac.th/files/ 08122511113930

Watananarong, K. (2007). Diffusion Theory. Chula press. 32-41

Paper submitted

Paper accepted for publishing

Paper published online
21 February 2019

14 April 2019

25 June 2019 